\title{
A Search for the Bacterial Mucopeptide Component, Muramic Acid, in Chlamydia
}

\author{
By A. J. GARRETT, ${ }^{*}$ MARGARET J. HARRISON $\uparrow$ \\ AND G. P. MANIRE† \\ The Lister Institute of Preventive Medicine, Chelsea Bridge Road, London SWI $W 8 R H$
}

(Received 27 July 1973)

\section{INTRODUCTION}

Chlamydiae are obligate intracellular parasites. They multiply by binary fission in a complex developmental cycle that involves a series of morphological forms. The mature infectious form, the elementary body, has a rigid wall similar in ultrastructure and amino acid content to the walls of Gram-negative bacteria (Manire \& Tamura, I967; Murray, I968; Tamura, Matsumoto, Manire \& Higashi, 197I). The intermediate form in multiplication, the reticulate body, lacks a rigid wall and is non-infectious.

Perkins \& Allison (1963) presented chemical evidence for the presence of muramic acid in several strains of Chlamydia: the P-4 pigeon strain of psittacosis, the Baker strain of feline pneumonitis, the T'ang strain of trachoma and the Nigg strain of mouse pneumonitis. The last-named strain was grown in tissue cell cultures, but the others were propagated in the yolk sacs of embryonate eggs. Jenkin (1960) reported traces of muramic acid in intact particles and walls of the Cal-Io strain of meningopneumonitis grown in the allantoic cavity of embryonate eggs, but no technical details were given. However, Manire \& Tamura (I967) were unable to detect muramic acid in purified intact elementary bodies or walls of the same strain grown in L cell cultures. Their method could not detect less than $20 \mu \mathrm{g}$ muramic acid and they concluded that the meningopneumonitis wall contained less than $0.2 \%$ of this compound.

The presence or absence of muramic acid in the genus Chlamydia has important implications for taxonomy, for theories of the replication of these organisms and for the mode of action of antibiotics to which they are susceptible. We have now used a very sensitive test to look for muramic acid in trachoma and meningopneumonitis agents grown in $\mathrm{L}$ cells.

\section{METHODS}

The fast-killing variant (Taverne, Blyth \& Reeve, I964) of trachoma agent strain TRIC/2/ $\mathrm{GB} / \mathrm{MRC}-4 / \mathrm{ON}$ was grown in L cell cultures in suspension (Garrett \& Harrison, 1973). The infected cells from six batches of 41 of infected $L$ cells were homogenized in a Teflon grinder and yielded a total of $3.4 \times 10^{12}$ inclusion-forming units (i.f.u.) (Furness, Graham \& Reeve, 1960; Taverne \& Blyth, 197I). The agent was purified by a slight modification of the method of Tamura \& Higashi (1963); before and after treatment with nucleases and trypsin, the preparation was centrifuged at $7500 \mathrm{~g}$ for $60 \mathrm{~min}$ at $4{ }^{\circ} \mathrm{C}$ through a $6 \mathrm{~cm}$ column of $25 \%$

* Present address: National Institute for Biological Standards and Control, Holly Hill, Hampstead, London NW3 6RB.

$\dagger$ Present address: Institut für Biochemie II, Universität der Heidelberg, 69 Heidelberg, Akademiestrasse 5, Germany.

* Present address: Department of Bacteriology and Immunology, School of Medicine, University of North Carolina, Chapel Hill, North Carolina 275 I4, U.S.A. 
$(\mathrm{w} / \mathrm{v})$ sucrose in $0.03 \mathrm{M}$-tris-hydroxymethylaminomethane- $\mathrm{HCl}, \mathrm{pH} 7 \cdot 4$. A total of $\mathrm{I} \cdot 3 \times 10^{12}$ elementary bodies was recovered, as measured by dark field microscopy (Reeve \& Taverne, I962). Electron microscopy showed that the purified preparations contained approximately as many reticulate bodies as elementary bodies. The dry weight of the total yield was estimated at 25 to $50 \mathrm{mg}$.

The Cal-Io strain of meningopneumonitis was grown in L cells, and elementary bodies and walls were isolated and purified by the method of Manire \& Tamura (1967) by Miss Tanaka at the University of North Carolina, Chapel Hill, U.S.A. Ninety mg dry weight of elementary bodies and $10 \mathrm{mg}$ wall material were examined for muramic acid.

A modification of the methods of Park \& Hancock (1960) and Mandelstam (1962) was used in an attempt to concentrate a mucopeptide fraction from elementary bodies and walls. All products were collected by centrifugation at Io000 $\mathrm{g}$ for I $5 \mathrm{~min}$ at $4{ }^{\circ} \mathrm{C}$. The chlamydia preparations were suspended in $5 \%(\mathrm{w} / \mathrm{v})$ trichloroacetic acid (TCA) at $0{ }^{\circ} \mathrm{C}$ for $\mathrm{I} h$. The insoluble material was washed with water and with $75 \%(\mathrm{v} / \mathrm{v})$ ethanol. It was then heated in $5 \%(\mathrm{w} / \mathrm{v})$ TCA for $6 \mathrm{~min}$ at $90^{\circ} \mathrm{C}$. The product was washed with water and resuspended in ethanol:ether $(3: 1, \mathrm{v} / \mathrm{v})$ at $20^{\circ} \mathrm{C}$; after $\mathrm{I} 8 \mathrm{~h}$ it was treated with $10 \mathrm{M}$-urea, $0.29 \mathrm{M}-2$ mercaptoethanol and $0.54 \mathrm{M}$-iodoacetic acid according to the method of Mandelstam (1962), and then incubated with crystalline pepsin (Sigma London Chemical Co. Ltd, Kingstonupon-Thames) in $0.05 \mathrm{M}-\mathrm{HCl}$ for $\mathrm{I} 8 \mathrm{~h}$ at $37^{\circ} \mathrm{C}$. The product was then washed once with $2 \mathrm{M}-\mathrm{NH}_{3}$, once with water, three times with $90 \%$ formic acid and twice with ether.

The preparations were hydrolysed in sealed ampoules in 4 M-hydrochloric acid at $100{ }^{\circ} \mathrm{C}$ for $4 \mathrm{~h}$. Hydrochloric acid was removed by evaporation under reduced pressure. The hydrolysates were streaked on Whatman no. $3 \mathrm{MM}$ chromatography paper, with markers of authentic muramic acid, and were run overnight in butan-1-ol:acetic acid: water (63:10:27, by vol.). Areas of the chromatogram with the same $R_{F^{\prime}}$ as the muramic acid markers were eluted with water. When Escherichia coli strain B organisms were fractionated in this way the final preparations contained $2 \%$ muramic acid, estimated colorimetrically by the method of Rondle \& Morgan (1955). It was assumed that chlamydia elementary bodies would contain insufficient muramic acid for colorimetric analysis: the eluates from the chromatograms of chlamydia hydrolysates were therefore treated with aqueous potassium $\left[{ }^{3} \mathrm{H}\right]$ borohydride (The Radiochemical Centre, Amersham, Buckinghamshire) and examined for $\left[{ }^{3} \mathrm{H}\right]$ muramicitol. After incubation at $20^{\circ} \mathrm{C}$ overnight the reaction mixture was acidified, dried under reduced pressure and washed four times with aqueous methanol. It was then run on a column of Dowex $50(\mathrm{H}+)(\times 8,200-400 \mathrm{mesh})$ equilibrated and eluted with $0.1 \mathrm{M}$-pyridine-acetic acid, $\mathrm{pH} 2 \cdot 8$ (Hughes, I970). Authentic muramic acid yielded $\left[{ }^{3} \mathrm{H}\right]$ muramicitol. The radioactivity of each fraction was measured in an Intertechnique ABAC SL 40 scintillation counter. Under these conditions the activity of a peak of $\left[{ }^{3} \mathrm{H}\right]$ muramicitol from $\mathrm{O} \cdot \mathrm{I} \mu \mathrm{g}$ authentic muramic acid was 200 counts/min. Eluates of the test material that showed activity in the same region as authentic $\left[{ }^{3} \mathrm{H}\right]$ muramicitol were streaked on either Whatman no. I or Whatman no. 4 paper with markers. They were run in butan-I-ol:pyridine: water $(6: 4: 3$, by vol.) overnight. The paper was cut into $0.5 \mathrm{~cm}$ strips to locate radioactivity with the same $R_{F}$ value as muramicitol. The efficiency of counting tritium on paper strips was $15 \%$ of that in liquid.

\section{RESULTS AND DISCUSSION}

Hydrolysates of our trachoma agent preparations were fractionated and reduced as described. A very small amount of tritiated material that corresponded with $\left[{ }^{3} \mathrm{H}\right]$ muramicitol was detected by chromatography on a Dowex $50(\mathrm{H}+)$ column and on paper. Formation of 
this product from a fraction co-chromatographing with muramic acid strongly suggested the presence of muramic acid in trachoma agent but paucity of purified agent precluded all the tests necessary for absolute proof. However, our results allow estimation of the maximum amount of this sugar present in trachoma agent. The material eluted from the Dowex column accounted for no more than $0.2 \mu \mathrm{g}$ muramic acid. Therefore, if we assume that the wall comprises $20 \%$ of the dry weight of trachoma elementary bodies, no more than $0.04 \%$ of the wall is muramic acid. We found no muramic acid in whole elementary bodies or in the purified walls of meningopneumonitis agent. Although mucopeptide certainly confers rigidity on the walls of Gram-positive bacteria, it is doubtful whether this component, alone, serves the same purpose in Gram-negative bacteria, in which only 5 to $10 \%$ of the wall is mucopeptide (Ghuysen, 1968); in the chlamydiae we examined, mucopeptide accounted for no more than $0.1 \%$ of the dry weight of the wall.

Although Perkins \& Allison (1963) detected muramic acid in several strains of Chlamydia, Manire \& Tamura ( 1967 ) found none in meningopneumonitis elementary bodies or walls. There are three possible explanations for this discrepancy:

(i) The assay method used by Manire and Tamura may have been insufficiently sensitive to detect the amounts of muramic acid present; they estimated that there could be no more than $0.2^{\circ}$ muramic acid in purified meningopneumonitis walls. Perkins \& Allison gave no estimation of the amount of muramic acid in their preparations but their methods detected smaller amounts of the sugar.

(ii) Autolysis during preparation of the walls used by Manire and Tamura may have dissolved the mucopeptide that was then lost during subsequent purification steps.

(iii) Reticulate bodies may contain mucopeptide, and elementary bodies little or none. Envelopes of bacterial spores differ from those of the vegetative form and contain less mucopeptide (Gledhill, 1967); the transition from reticulate to elementary bodies may resemble sporulation in this respect at least. Our preparations of trachoma agent contained reticulate bodies and elementary bodies; the meningopneumonitis agent preparation contained only elementary bodies. The Chlamydia preparations used by Perkins \& Allison (1963) probably contained reticulate bodies; Lawn, Blyth \& Taverne (I973) observed all the developmental forms of trachoma agent in yolk sac preparations which had been partially purified by trypsin treatment and differential centrifugation, and in trachoma-infected BHK-2I cells.

Mucopeptide may play a role in maintaining the integrity of the wall during development of chlamydiae but it is extremely unlikely that it acts as a mechanical support. Tribby (I 970) proposed that reticulate bodies of meningopneumonitis agent have flexible walls containing uncrosslinked mucopeptide. She also suggested that crosslinking of the mucopeptide is necessary for the formation of the more rigid walls of elementary bodies, and that pencillin interferes with this reaction. However, Tamura \& Manire (I968) showed that penicillin inhibits the replication of reticulate bodies and not only the formation of elementary bodies. All penicillin-sensitive bacteria studied so far have the same general mucopeptide structure of polysaccharide 'backbones' composed of alternate residues of $\mathrm{N}$-acetylglucosamine and $\mathrm{N}$-acetylmuramic acid joined by a network of crosslinked peptides. Penicillin is now believed to inhibit transpeptidation of the mucopeptide of these bacteria (Strominger, Izaki, Matsuhashi \& Tipper, 1967) and growing cells synthesize a defective wall and eventually lyse. Penicillin could affect chlamydiae in a similar way, but it may inhibit the crosslinking of peptides that are not attached to a polysaccharide containing muramic acid. Now that it is agreed that chlamydiae are more closely related to bacteria than to viruses, some authors too readily ascribe well-established properties of free-living bacteria to them. Only gross chemical analyses of the envelope of one strain of meningopneumonitis have been done; the 
presence of mucopeptide is still in doubt, and it could well be that in these unique microorganisms penicillin acts in a unique way. Until more is known about the chemical structure and the biosynthesis of chlamydial cell walls, we should avoid drawing too close an analogy between the Chlamydia and bacteria.

We thank Miss Lynne Hughes and Miss Nicci Yianni for excellent technical assistance. The study was supported in part by a Research Fellowship (to M.J.H.) from the Wellcome Trust and in part by Grant AI-00868 from the National Institute of Allergy and Infectious Diseases, U.S. Public Health Service.

\section{REFERENCES}

Furness, G., Graham, D. M. \& Reeve, P. (1960). The titration of trachoma and inclusion blennorrhoea viruses in cell cultures. Journal of General Microbiology 23, 613-619.

GarretT, A. J. \& HARrison, M. J. (1973). The development of a TRIC agent (Chlamydia trachomatis) and its associated polysaccharide in suspended cell cultures. Journal of General Microbiology 78, $297-303$.

GHUYSEN, J. M. (I968). Use of bacteriolytic enzymes in determination of wall structure and their role in cell metabolism. Bacteriological Reviews 32, 425-464.

Gledhill, W. E. (1967). Glycopeptide synthesis during sporulation of Bacillus megaterium. Canadian Journal of Microbiology 13, I6I 5-1620.

Hughes, R. C. (1970). Autolysis of isolated cell walls of Bacillus licheniformis N.C.T.C. 6346 and Bacillus subtilis Marburg strain I68. Biochemical Journal $\mathbf{1} \mathbf{9}$, 849-860.

JENKIN, H. M. (1960). Preparation and properties of cell walls of the agent of meningopneumonitis. Journal of Bacteriology 8o, 639-647.

Lawn, A. M., BLyth, W. A. \& Taverne, J. (I973). Interactions of TRIC agents with macrophages and BHK-2 I cells observed by electron microscopy. Journal of Hygiene 7I, I-I 4.

Mandelstam, J. (I962). Preparation and properties of the mucopeptides of cell walls of Gram-negative bacteria. Biochemical Journal 84, 294-299.

Manire, G. P. \& Tamura, A. (1967). Preparation and chemical composition of the cell walls of mature infectious dense forms of meningopneumonitis organisms. Journal of Bacteriology 94, 1 I $78-1183$.

Murray, R. G. E. ( 1968). Bacterial cell wall anatomy in relation to the formation of spheroplasts and protoplasts. In Microbial protoplasts, spheroplasts, and L-forms, pp. I-I 8. Edited by L. B. Guze. Baltimore: Williams and Wilkins.

PARK, J. T. \& HANCOCK, R. (1960). A fractionation procedure for studies of the synthesis of cell-wall mucopeptide and of other polymers in cells of Staphylococcus aureus. Journal of General Microbiology 22, 249-259.

Perkins, H. R. \& Allison, A. C. (I963). Cell-wall constituents of rickettsiae and psittacosis-lymphogranuloma organisms. Journal of General Microbiology 30, 469-480.

Reeve, P. \& TAVerne, J. (1962). A simple method for total particle counts of trachoma and inclusion blennorrhoea viruses. Nature, London 195, 923-924.

Rondle, C. J. M. \& Morgan, W. T. J. (I955). The determination of glucosamine and galactosamine. Biochemical Journal 6r, 586-589.

Strominger, J. L., Izaki, K., Matsuhashi, M. \& Tipper, D. J. (1967). Peptidoglycan transpeptidase and D-alanine carboxypeptidase: penicillin-sensitive enzymatic reactions. Federation Proceedings $\mathbf{2 6}$, 9-22.

TAmura, A. \& Higashi, N. (1963). Purification and chemical composition of meningopneumonitis virus. Virology 20, 596-604.

Tamura, A. \& Manire, G. P. (I968). Effect of penicillin on the multiplication of meningopneumonitis organisms (Chlamydia psittaci). Journal of Bacteriology 96, 875-880.

Tamura, A., Matsumoto, A., Manire, G. P. \& Higashi, N. (I97I). Electron microscopic observations on the structure of the envelopes of mature elementary bodies and developmental reticulate forms of Chlamydia psittaci. Journal of Bacteriology 105, 355-360.

Taverne, J., Blyth, W. A. \& Reeve, P. (1964). Toxicity of the agents of trachoma and inclusion conjunctivitis. Journal of General Microbiology 37, 27 I-273.

TAVERne, J. \& BLyth, W. A. (1971). Interactions between trachoma organisms and macrophages. In Trachoma and Related Disorders Caused by Chlamydia Agents, pp. 88-107. Proceedings of a symposium held in Boston, Massachusetts, August 1970. Edited by R. L. Nichols. Amsterdam: Excerpta Medica.

TriBbY, I. I. E. (1970). Cell wall synthesis by Chlamydia psittaci growing in L cells. Journal of Bacteriology I04, I I 76-I I 88 . 